Article

\title{
From a Three-Legged Stool to a Three-Dimensional World: Integrating Rights, Gender and Indigenous Knowledge into Sustainability Practice and Law
}

\author{
Lori DiPrete Brown ${ }^{1,2,3, *}$, Sumudu Atapattu ${ }^{2,4, *}$, Valerie Jo Stull ${ }^{1,2}$, \\ Claudia Irene Calderón ${ }^{2,5} \mathbb{D}$, Mariaelena Huambachano ${ }^{2,3}{ }^{\mathbb{D}}$, Marie Josée Paula Houénou ${ }^{6}$, \\ Anna Snider ${ }^{7}$ and Andrea Monzón ${ }^{8}$ \\ 1 Global Health Institute, University of Wisconsin-Madison, Madison, WI 53706, USA; vstull@wisc.edu \\ 2 4W Initiative-Women and Wellbeing in Wisconsin and the World, University of Wisconsin-Madison, \\ Madison, WI 53706, USA; cicalderon@wisc.edu (C.I.C.); huambachano@wisc.edu (M.H.) \\ 3 School of Human Ecology, University of Wisconsin-Madison, Madison, WI 53706, USA \\ 4 Law School \& Nelson Institute for Environmental Studies, Human Rights Program, University of \\ Wisconsin-Madison, Madison, WI 53706, USA \\ 5 Department of Horticulture, University of Wisconsin-Madison, Madison, WI 53706, USA \\ 6 Founder of WESISAH, C40 City adviser, Abidjan 22 BP 757, Cote d'Ivoire; mariejoseehouenou@gmail.com \\ 7 Department of Agricultural and Consumer Economics, University of Illinois Urbana-Champaign, \\ Champaign, IL 61820, USA; asnider@illinois.edu \\ 8 MealFlour Director of Programs, Quetzaltenango 09001, Guatemala; andrea@mealflour.org \\ * Correspondence: dipretebrown@wisc.edu (L.D.B.); sumudu.atapattu@wisc.edu (S.A.)
}

Received: 2 October 2020; Accepted: 7 November 2020; Published: 16 November 2020

\begin{abstract}
Sustainable Development" has come a long way since the World Commission on Environment and Development first popularized the term in 1987. Virtually everyone is now familiar with the term Sustainable Development, from states to multinational corporations, and from affluent communities in the Global North to impoverished communities in the Global South. It received a new lease of life in 2015 when the United Nations General Assembly adopted Agenda 2030 and Sustainable Development Goals (SDGs). It is recognized that sustainable development requires an inter-disciplinary, multi-level, and bottom-up approach, and that this ideal is easy to state but difficult to operationalize. Pursuant to deliberations at an international workshop at the University of Wisconsin-Madison, which aimed at fostering the exchange of ideas among diverse experts and developing solutions for effective inclusion of women and youth in climate change response strategies, we propose an innovative, practical three-dimensional model that enhances sustainability theory and practice with cross-cutting integration of human rights, gender equity, and Indigenous and local knowledge. We evaluate the utility of the model in two ways: First, we analyze how the model informs current approaches to environmental sustainability and human wellbeing including the SDGs, agroecology, de-growth principles, and planetary health metrics. Then, we explore the feasibility and added value of the approach through seven case studies from Guatemala, Sri Lanka, Malawi, Peru, Côte D'Ivoire, and Aotearoa-New Zealand. We conclude that the proposed model is congruent with current theory and practice. It builds on existing principles by identifying and addressing gaps. It enables practical action in a variety of settings and fosters a more integrated approach to sustainable wellbeing for humanity and our earth. We recommend continued development of this theoretical framework and related guidelines for program design, implementation and evaluation.
\end{abstract}

Keywords: sustainable development; human rights; gender equity; local and Indigenous knowledge; de-growth; planetary health; agroecology; sustainable development goals 


\section{Introduction}

"Sustainable development" has come a long way since the World Commission on Environment and Development first popularized the term in 1987, and now every single region of the world is familiar with the goals of sustainable development. Sustainable development received a new lease of life in 2015 when the United Nations General Assembly adopted Agenda 2030 and Sustainable Development Goals (SDGs). However, what does sustainable development mean? This question was debated at our recent workshop on gender and climate change at the University of Wisconsin-Madison [1]. On one end of the spectrum are those who believe that it is ambiguous and a difficult concept to define and operationalize. On the other are those who believe that a new branch of international law called "international sustainable development law" has emerged [2]. This topic has also received the attention of the World Court and other tribunals and a substantial body of jurisprudence on sustainable development has emerged [3]. While, sustainable development is not confined to the law, clear and comprehensive legal and conceptual frameworks are essential if the needed inter-disciplinary, multi-level, and bottom-up approach is to be codified appropriately, and adopted, adapted and scaled effectively. For this reason, we offer a new three-dimensional model for sustainability work in a legal context, with the aim of developing related law, policy and practice.

Sustainable development encompasses three goals-environmental protection, economic development and social development [4-6]. Some equate it to a three-legged stool. However, this three-legged stool depiction has been critiqued by Dawe and Ryan because "with this model, humanity is once again placed outside the environment". They argue that:

"Simply put, humanity can have neither an economy nor social wellbeing without the environment. Thus, the environment is not and cannot be a leg of the sustainable development stool. It is the floor upon which the stool, or any sustainable development model, must stand. It is the foundation of any economy and social wellbeing that humanity is fortunate enough to achieve" [7]

We agree with Dawe and Ryan that the environment must be considered the floor upon which sustainable development must stand, not just another "leg" of the sustainable development stool. We also believe that the environment cannot be seen as separate from human life, in a flat two-dimensional array that abridges too aggressively and leaves out particular histories, lived experiences, and the interconnectedness of life forms. Rather, we need models and metaphors that reflect the reality that humans and the environment form an integral whole, a continuum, a sustainable three-dimensional space for life.

The authors came together at the University of Wisconsin-Madison for an international workshop that focused on gender and climate change in September of 2019 [1]. The aims were shared learning, identification of research priorities, and insights about more comprehensive models and frameworks for sustainability. During the workshop case studies from around the world were shared and presenters were asked to comment on how their work related to planetary health, the sustainable development goals, and gender analysis. Comparative analysis and discussion revealed consensus that gender analysis needed more attention at the community, national, and international policy levels. In addition, and importantly, attendees identified two more significant gaps related to human rights and indigenous ways of knowing and being.

Therefore, we posit this three-dimensional model (3D model) which integrates: (1) Human rights and related legal frameworks; (2) gender analysis and gender mainstreaming practices, and (3) local and Indigenous history, knowledge and ways of knowing. Further, we explore concepts and practices related to climate change and gender equity, the SDGs, human right, and Indigenous knowledge. The fundamental dimensions of our proposed 3D model are described below.

Human Rights. With its emphasis on non-discrimination and protection of marginalized groups, a human rights-based approach informs both sustainable development and environmental justice [8]. This is essential given that human activity has the potential to sustain or degrade environmental 
wellbeing, and these environmental impacts affect marginalized communities disproportionately. The social pillar of sustainable development has brought human rights law within the sustainable development paradigm ${ }^{3}$. Examining the link between environmental justice and sustainability, Agyeman et al., propose "just sustainability" as a framework, which they define as "the need to ensure a better quality of life for all, now, and in the future, in a just and equitable manner, while living within the limits of supporting ecosystems [9]". While human rights encompass gender and indigeneity, additional tools and approaches are necessary to fully incorporate these aspects.

Gender-sensitive Approaches. Similarly, gender-sensitive approaches, defined as those that include the lived experience of women and men, and the varied experience of gender, is an essential lens for understanding and envisioning systems that support life. A fully intersectional perspective takes into account, race, ethnicity, ability and also provides a methodology that can be applied broadly across historically marginalized groups. Further attention as to how gender is constructed, gender roles and norms, the presence of gender discrimination, and the degree to which sustainability metrics attend to gender, from basic disaggregation by sex to selection of quality of life measures that reflect gender roles and differences [10]. Gender approaches include specialized tools from a variety of fields to describe and respond to household and societal dynamics and differential impacts related to sex and gender associated with development, but also include the important role of gender diversity in leadership for change.

Indigenous and Local Knowledge. Awareness of the rights and assets of Local and Indigenous communities, and the need to draw on particular histories and alternative systems of knowledge, as a matter of both justice and survival is on the rise. Global development agendas, such as the SDGs, highlight the significance of local solutions - not least those embedded in traditional ecological and local community knowledge-for global sustainable development. For example, Indigenous 'traditional' food systems or foodways are part of the ancestral cultural knowledge of Indigenous peoples. They do not solely focus on food as a calorie count of diet, instead emphasizing physical and spiritual wellbeing. This holistic way of understanding living systems is an essential mindset for a just, sustainable future [11].

Understanding our work in the era of COVID-19. We offer this model during a global pandemic with complex and long-lasting impacts on every aspect of life. While, times of crisis often result in a pause of long-term holistic thinking, we feel that in these times more than ever, simple inclusive and value-based constructs are needed to guide research and provide clarity of purpose to collective action. Systems science involves an understanding of the complexity and inevitability of crises and systemic shocks. Such complex emergencies can be expected to occur more frequently due to global challenges related to environmental degradation, pressures associated with patterns of resource use and consumption, climate change, disease outbreaks like COVID-19, and historic breaking points related to inequities associated with poverty, racism and colonization. As we reflect on our partnerships and the case studies that describe our collaborations, we are reminded that local and Indigenous communities, in fact, the majority of the human family, live with significant disruptive conditions (floods, family, lack of access to food and water, war) that they must address concurrently as they attempt to survive, live sustainably in their environments and thrive. Therefore, we propose that justice and inclusion, and sustainable development be recognized as essential priorities at all times.

In the following sections we offer an innovative, practical and overlapping three-dimensional (3D) sustainability matrix based on human rights, gender equity, and indigenous and local knowledge (Table 1 offers guiding questions for this model). We evaluate this model vis-a-vis current sustainable development frameworks and provide case studies that explore its utility from varied experience in seven communities. Finally, we draw lessons and implications for further development, law, policy and practice. 


\section{Part 1: Integrating Human Rights, Gender Equity, and Indigenous Knowledge: The 3D Model and Common Sustainability Approaches}

To determine if our proposed 3D approach can enhance the effectiveness and impact of existing sustainability approaches, we analyze here four common sustainability approaches: The Sustainable Development Goals, De-growth, Agroecology, and Planetary Health. While, each of these have rich and nuanced literature associated with them, here, we consider the fundamental core concepts that drive policy, practice and the public discourse. Having identified these basic ideas, we consider whether the approach adequately addresses the three dimensions, and whether the 3D model adds to the explanatory or prescriptive power of the strategy in question (see Table A1 in Appendix A).

The Sustainable Development Goals reflect 17 inter-related goals with sub-goals and metrics ranging from addressing poverty, food, water, education, health, gender equity, and climate change. They are based on the premise that economic growth and environmental sustainability can work in alignment within a framework of human rights and justice. SDGs recognize the interconnections between goals. In 2019, six clustered "transformations" related to education, health, energy, food and water, cities, and the digital revolution were articulated [12].

Human rights underlie the realization of SDGs and the SDGs are seen as a pre-condition for the realization of rights. SDGs rely heavily on a development or economic rationale than rights-based imperatives. Elevating human rights as both means and end could strengthen SDGs and reconcile differences with other models.

Gender equality is one of the goals (SDG 5) that recognizes that gender is important in relation to many aspects of development but does not integrate gender or address the full range of gender-related identities. Goal 5 focuses most heavily on women as a protected group, as a matter of justice, and places less emphasis on the importance of women's leadership in society and the full range of gender identities.

Indigenous communities are mentioned in SDGs in relation to increasing food productivity of small farms and access to education for Indigenous children. Many SDGs are aligned with Indigenous values, but these linkages are not fully articulated. Indigenous knowledge that supports integration and holistic understanding and practice could strengthen SDGs in terms of clarity, meaning, purpose, and related actions. Indigenous perspectives in particular highlight the centrality of land, water and food, and environmental stewardship for sustainable development [13].

De-growth approaches challenge the idea that growth is sustainable or necessary for humans and the environment to thrive, seek to redistribute resources, and downscale production and consumption. It is a transformative approach where units of production and metabolism of resources will be both smaller and different. De-growth aims to distribute both assets (land and resources) and risks (pollution, waste, resources insecurity) more equally and more justly, recognizing that the basic needs of those who need (mostly in the Global South) need to be met [14]. De-growth approaches focus on equity and are aligned with human rights. However, they tend to address problems within economics with alternative economics. A more explicit rights-based process could strengthen the effectiveness and political feasibility of de-growth approaches.

De-growth approaches are not explicit about gender equity though the overall equity claim does imply better quality of life for women. As complex developed and mechanized societies are critiqued, a gender lens is useful and important to ensure that labor is distributed with equity and that economic devolution does not have the unintended consequence of sustaining or re-introducing disparate burdens related to gender roles.

Local and Indigenous knowledge is an important resource for de-growth approaches. While some de-growth approaches do draw on practices, or specific cultural articulations of the good life, there is not a systematic focus on local and Indigenous knowledge in the de-growth movement-which is more focused on critiquing the economic status quo. De-growth approaches would be strengthened by using this knowledge as a foundation for alternative economics and conceptualizations of value and quality of life. 
Agroecology is an alternative approach to food production that challenges the dominant agricultural paradigm by paying closer attention to the interactions of plants, soil, soil organisms, insects, environmental conditions and management practices with the surrounding natural ecosystems. Agroecology draws on ecological concepts and principles to transition towards sustainable food production systems that meet human needs while preserving the integrity of the environment. In doing so, it also incorporates a socio-political component by encouraging the analysis of traditional ecological knowledge, human consumption patterns, unequal distribution of food, among others. Strategies include, for example, use of heritage seeds, recycling of nutrients in the fields, regeneration of soil matter, integrated pest management, and avoidance of external inputs $[15,16]$.

Human rights are implicit in the agro-ecological emphasis on community, harm avoidance, and food sovereignty and environmental stewardship. Inclusive science that embraces traditional knowledge is deeply aligned with human rights. While, demonstration is the key to scale, human rights principles will enhance practice and be a good tool for advocating scale up as a moral imperative.

This approach seeks to respect and give voice to the knowledge and agency of women. While, some gender empowerment is implicit in this model and women are clear beneficiaries of the self-reliant approach, it could benefit from explicit acknowledgement of the equality of women. Attention to equitable division of labor in the household and community is important for this approach to achieve its full potential. Further, promotion of women in STEM (science, technology, engineering and mathematics) is also needed. Like the other models, agroecology does not address explicitly the lived experience of the full range of gender identities.

This model embraces Indigenous and local practices respectfully but could benefit from fuller inclusion of Indigenous knowledge, including social, philosophical ways of knowing, as well as Indigenous science.

Planetary health relates human activity and health to nine natural processes that regulate the stability of the earth system. Metrics and boundaries are identified as: Ozone depletion, biodiversity, chemical pollution, climate change, water systems, nitrogen and phosphorus levels, and aerosol load. The focus is on the health, not just of people or populations, but of human civilization and the state of the natural systems on which it depends $[17,18]$. The planetary health rationale is articulated in terms enlightened self-interest for humans and also references the rights of human civilization. As this theory evolves, a more explicit and legal analysis of how human rights support planetary health goals would be useful.

Planetary health is gender-informed to the degree that it subsumes fields such as global health, eco-health and one health, all of which have only partial articulation or inclusion of gender equity. Gender equity in STEM fields and planetary health leadership is a critical first step. As the links between planetary health metrics and other more human-centered and place-based metrics are developed, attention to gender-inclusive approaches to selection of metrics and disaggregation of data by sex would be important.

Indigenous ways of understanding the relationships between people, the land and life can inform the nascent attempt to deal with these ontological concepts within planetary health. On the one hand, planetary health is grounded in scientific boundaries, and on the other, the desire to perpetuate the whole of human civilization. There is not yet a clear articulation of what it means at place-based and local scales, or how these two are connected. Local and Indigenous knowledge (along with more input from the social sciences and humanities) can help it to articulate its aims in terms of survival and preservation in more place-based historically contextualized ways.

This exploratory analysis of the 3D model demonstrates its generative power and suggest that, with further development it can: (1) Enrich the effectiveness and equity of sustainability efforts, by helping to identify and respond to theoretical and practical gaps; (2) provide a flexible structure for learning and sharing across settings, even where different strategies are being used; (3) provide a simple framework for community engagement and collective action; and (4) enable synergy and integration, and perhaps resolve tensions among the dominant sustainability frameworks. 


\section{Part 2: Practice Implications: Case Studies from Seven Communities}

In order to further explore whether the 3D model enhances sustainability practice we chose to retrospectively look at projects from our workshop along with selected case examples from our interdisciplinary group of scholars, as a proof of concept. We selected projects that had, implicitly or explicitly, experienced success with at least one of the three dimensions. Researchers also assessed whether the other dimensions were addressed. Further, they and field partners were asked to consider whether they felt that use of the 3D model from the outset would have improved the project's processes and/or outcomes, or if 3D thinking could potentially do so in the future. We present experience from seven communities: (1) Guatemala Agroecology (Calderón); (2) Malawi (Snider); (3) Guatemala MealFlour (Stull and Monzón); (4 and 5) Peru and Aotearoa New Zealand (Huambachano); (6) Côte D'Ivoire (Houénou); and (7) Sri Lanka (Atapattu) that address a broad range of sustainability issues. The work occurred at different scales and with different sustainable development approaches. The breadth of cases provided a robust context for evaluation of the practical validity of the 3D model.

In order to facilitate comparative analysis, we developed a set of questions that each researcher was asked to address in the case study. It was understood from the outset that none of the case studies would address all three dimensions. Rather, the focus of the tri-partite analysis was to determine whether the dimensions would have led to specific changes or improvements to the project or could do so in the future.

Table 1 presents the questions that researchers used as a guide and are followed by the case studies. Unless otherwise noted, each case was developed by the above-named researcher(s), reviewed and revised with collaborators for additions and accuracy.

Table 1. 3-D Guiding Questions for Comparative Case Studies.

\begin{tabular}{ll}
\hline Dimension & Critical Questions \\
\hline & What are the human rights that are affected in the case study? Were there any human rights \\
infringed? Consider the main human rights instruments as a guide-Universal Declaration of \\
Human Rights (1048) [19], International Covenant on Civil and Political Rights (1966) [20], \\
International Covenant on Economic, Social and Cultural Rights (1966) [21], Convention on \\
the Elimination of All Forms of Discrimination Against Women (1979) [22] and the UN \\
Declaration on the Rights of Indigenous Peoples (1997) [23] \\
Was information provided to the community in a language they could understand? \\
How were the decisions made? Did the officials involved get the participation of the affected \\
people in making decisions? How were they consulted? \\
Was it necessary to adopt special provisions with regard to this particular community which \\
may not be necessary in relation to other communities? \\
If it was hard to avoid the infringement of rights in this case, how did the decision makers \\
balance the rights involved? Were the affected groups/individuals provided relief? \\
What are the relevant gender roles and how will they be affected by the activity? Will the \\
activity reduce hardship or shift tasks from women's work to men's work, for example? \\
Did the collaborators reference the relevant provisions of the Convention on the Elimination \\
of All Forms of Discrimination Against Women 1979 (CEDAW) [22] as a yardstick to ensure \\
gender equality? \\
Did the project address gender-based constraints (for example, time constraints, access to \\
land or credit, physical constraints, social norms) in access to the activity? \\
How did the activities impact gender dynamics within the household? (decision-making \\
power, earning power, responsibility) \\
ow did the activity impact gender dynamics outside the household? \\
(women's leadership, gender norms, acknowledgement and inclusion of all genders) \\
Have you gone beyond sex disaggregated data to consider the multiple roles of men and \\
women throughout their lives and how that influences their role in the household, society \\
and the proposed activity?
\end{tabular}


Table 1. Cont.

\begin{tabular}{ll}
\hline Dimension & Critical Questions \\
\hline & What role does 'Indigenous or local knowledge' play in the case? \\
Local and & Was a "worldview" with respect to sustainability articulated? \\
Indigenous & How did the case consider the relationship between land, worldviews and knowledge \\
Knowledge & $\begin{array}{l}\text { What strategies were used to identity, safeguard and promote cultural knowledge? } \\
\text { What is the role of traditional ecological knowledge in the case study (TEK)? What barriers } \\
\end{array}$ \\
& and challenges are faced by the community in efforts to preserving TEK? \\
\hline
\end{tabular}

\subsection{CASE STUDY 1: Guatemala: Agroecology for a Sustainable and More Inclusive Food System}

The SDGs address global challenges and suggest actions to achieve a more sustainable future for all. In particular, SDG 2 is focused on eradicating hunger, which raises the question of how to feed a predicted 11 billion population by 2100 [5]. Reflections on how to create a food system that can provide nutritious food for all without causing adverse consequences to humans, animals and natural habitats is urgent. The food system, and every step along its value chain from production to marketing, is a social determinant of global health and one of the most significant drivers of environmental change. A number of studies suggest a connection between the use of agrochemicals in agriculture and their adverse effects on chronic disease; diabetes, obesity, heart disease- and the increased spill-over of zoonotic diseases (foodborne illnesses, and other infectious disease outbreaks that have the potential to become or actually become global pandemics like Ebola, swine and avian flu, or severe acute respiratory syndrome coronavirus) [24-28].

The prevailing industrialized food production system, inspired by the Green Revolution, has allowed for high yields and reduced undernourishment as measured by protein and calorie intake. In Guatemala, the agricultural extension of food production is delivered as a top-down transfer of technical solution packages that promote reliance on agricultural inputs and often on patented seed varieties. Unfortunately, focusing solely on calorie count does not necessarily translate to the reduction in micronutrient deficiencies. The 2019 Lancet Report suggests, for instance, that obesity, undernutrition and climate change constitute a syndemic or a synergy of epidemics that are driven by food and agriculture, land use and urbanization [29]. If we follow current trends of food production, predictive models suggest an unprecedented increase in environmental damage caused by deforestation, water and air pollution; together with the need for more arable land, and a surge in the global amount of nitrogen, phosphates and pesticides used.

The Project. Red Kuchub'al [30], an association of small-holder farmers in Guatemala, has created an alternative road that could lead to a resilient food system that promote community self-reliance and benefit, not only humans, but the soil, water, animals and plants in their ecosystem [24-28].

Red Kuchub'al works under the principles of solidarity, commitment to the environment, transparency and equity. They make use of practices that are rooted on agroecological principles $[15,16]$. In contrast to standard commodity food production methods that operate under the paradigm of modernizing agricultural systems, small holder agroecological farmers make use of knowledge systems that are tied to their cultural and historical landscapes.

Applying the 3D Framework. While, human rights are not explicitly mentioned in the mission of Red Kuchub'al, their principles are aligned with the rights to food, health, livelihood, an adequate standard of living, and equity across genders, generations, and ethnicities. The work of this organization has implications for several SDGs: SDG 1 (poverty); SDG 2 (hunger); SDG 3 (health and wellbeing); SDG 5 (gender equality); SDG 12 (responsible consumption and production); and SDG 15 (life on land) [4].

The adoption of agroecological practices by Red Kuchub'al has permeated gender dynamics and is transitioning towards more balanced gendered scenarios in the even distribution of education opportunities between boys and girls [31]. The organization of young and adult women collectives through women-led entrepreneurship (i.e., production and commercialization of tea, coffee, chocolate, 
soap, elderberry jam, canned peaches) have allowed cash generation that has been re-invested in these projects to purchase equipment and supplies or invested in their households. There is an increased participation of women in leadership roles (i.e., president of community associations), that have been well-received within the household and community members, and the support of Red Kuchub'al has been instrumental in combating gender-blind agroecology by promoting gender equity training, and addressing new masculinities with farmers in the area. Nevertheless, there are still challenges related to gender gaps. Women, for instance, are still burdened with the bulk of the domestic responsibilities, and the gender divide continues in access to education, cellphones, internet, land tenure, credit, pay, and formal training continues.

A derived infringement of basic human rights, such as access to food and clean water forces new ruralities, whereby mobilization to urban areas or transnational labor migration, particularly of youth, poses a threat to the sustainability of food production in the area. Feminization of agriculture is driven by off-farm employment and migration. On the one hand, women are being hired in seasonal employment that is precarious in nature, poorly paid and with limited flexibility for professional growth [32,33]. On the other, women become household leaders while their husbands are migrating to the United States, in charge of both parenting responsibilities, work in the field and providing for their families.

Addressing gender inequality can have a huge impact on the scaling of agroecological practices. It has the potential to strengthen rural subjectivities characterized by land ethics and self-reliance. A gender-sensitive agroecology can promote nature-based solutions for development, by safeguarding community-based knowledge, in situ conservation of locally adapted crops and landraces, reinforcing local food culture, and upholding the environmental rights of future generations.

Mam Indigenous groups in the Guatemalan highlands act as counter-hegemonic resistant units against mainstream agricultural paradigms. Specifically, the area surrounding Volcano Tacana, illustrates an overlap between pre-Hispanic agriculture and agroecology. For example, traditional agricultural ways include the use of Milpa, a traditional intercropping system that includes maize, bean, squash and other plants, such as amaranth or chili, for example. Agricultural fields usually have high crop diversity (including annual and perennial crops) that contributes to resilience in the agroecosystem against climate change. These producers allow the recycling of nutrients, have a strong land ethics adherence, and a deep concern for community wellbeing. Unique features of this group's agricultural practices are deeply entrenched in their Cosmovision. For instance, the checking the moon phases to inform the best days for sowing the land or harvesting the year's crops is still a common practice. It is not unusual to observe a synchrony between ancient Mam rituals and Catholic ceremonies in the blessing of the seeds. Additional training in agroecological practices have validated transgenerational knowledge and promoted new and diverse agricultural practices that promote wellbeing.

Climate change is an underlying variable that permeates the 3D sustainability matrix developed in this paper. Unpredictable weather patterns have been perceived in the western highlands of Guatemala by these rural and Indigenous farmers. The self-reliance of the communities is challenged by the relentless confluence of droughts, floods, increased temperatures and the lack of governmental investments in rural developments.

Conclusion. Resilience building through the adoption of agroecological practices can be a transformative process of strengthening the capacity of the communities to better absorb and bounce forward from crises, to transition towards healthy, sustainable and just food systems. The question remains whether this localized example of solidarity economy and resilience rooted in agroecology be scaled up and adapted to other contexts?

\subsection{CASE STUDY 2: Co-Creation of Gender-Integrated Agricultural Extension Tools in Malawi}

The author was requested to provide training for extension workers of a USDA-funded activity to mainstream gender throughout their agricultural extension programming. 
The Project. MSIKA, an agricultural value chain development project in Malawi, implemented by Land o' Lakes International Development (now Venture 37), aims to increase agricultural productivity of smallholder female and male farmers, and expand the trade of agricultural products. The project is designed to benefit 42,000 smallholder farmers organized in farmers' organizations by improving crop productivity, facilitating improved food processing and reducing post-harvest losses.

The beneficiaries of the project are diverse in terms of religion (Muslim and Christian), tribes, and land tenure systems (belonging to matrilineal and patrilineal tribes). The Malawi Growth and Development Strategy III outlines a path to a productive and resilient population by linking growth with attainment of the SDGs (Government of Malawi, 2017). Certain cultural practices in Malawi may deny women property rights or limit their decision-making-power about how to use their land [34]. This contributes to the proportionally higher rate of poverty among women in Malawi and inhibits attainment of SDG 5 (gender equality) [4]. An individual is not able to contribute to the sustainability of their environment if she or he lacks control over the resources to do so [35].

A baseline survey found that a lack of women's decision-making power within the household limited the say women had in land use and the sale of horticultural crops, affecting both women's control over household resources and household nutrition. Seventy-three percent of the individuals surveyed (male and female) had a negative perception of women's empowerment and expressed concerns about disrupting the balance of power in households if women became "too empowered". There were many farmers' organizations in the area working on horticultural value chains, and more were created throughout the life of the project, but women's leadership in the organizations was low.

Objectives. The goal of the training was to create sensitivity among extension workers to the issue of women's equity in benefitting from the project while respecting local customs and worldviews. Extension workers employed by the project had no prior gender training and were unequipped to deal with gender issues relevant to their programming. Discussions with the extension workers also revealed mixed opinions about women's empowerment. Promoting women's empowerment and participation in value chains was part of their mandate as extension workers, but they did not completely understand their role. While the extension workers believed that women should play a larger role in the management of farmers' organizations, they believed the status quo was best addressed at the household level. There was also misunderstanding of the concepts of gender and gender issues were often confounded with sexual harassment and gender equity was confused with equality of access. A top-down gender curriculum would create the feeling that outside worldviews were being imposed on local communities.

Applying the 3D Framework. A co-creation approach was needed so that the extension workers would feel ownership for the material, incorporate local worldviews, and would develop an understanding about what empowerment means in the local context. Considerable time was taken during the training to discuss the extension workers' opinions and perceptions of gender as it relates to agricultural extension. This was followed by an introduction to gender equity and gender mainstreaming. As women's empowerment was a contentious topic and as extension workers and beneficiaries alike misconstrued women's empowerment as taking power away from men, the concept of farmer empowerment (everyone having control over his or her own resources) was used. The extension workers were given gender lesson plans from several different training curricula including Integrating Nutrition and Gender within Agricultural Extension Services (INGENAES), Gender Action Learning System (GALS), and a lesson plan developed by the author.

The extension workers were divided into groups. Each group chose a lesson plan, studied it, and presented it later to the group. The entire group commented on each lesson plan, what they liked, what they did not like, and how it could be changed or adapted to be more locally relevant. Some lesson plans were rejected as not culturally appropriate and four lessons were chosen, which the extension workers liked, accepted as culturally appropriate, and felt comfortable presenting to project beneficiaries. Some extension workers acknowledged that they would make adjustments to the lessons, based on the community in which they were working, considering the religion and culture of 
the participants. The following day, the trainees became trainers, and presented the chosen lesson plans to a farmers' organization in the area. The extension workers took ownership of the lessons, added locally known anecdotes from folklore to illustrate concepts, such as "power over" and "power with," and acted out short skits to model couples respectfully discussing and making joint decisions about the use of household resources. Then, they asked the participants to illustrate the concepts that they had just learned into their own depictions so that they could remember the concepts, put them into their own terms and explain them to others in their organization or household in their own language. As a result of the training, the project beneficiaries have elected more women in leadership positions and women are taking a more active role than before. From the 217 farmers' organizations in the project, 210 have elected women to positions of leadership.

Conclusion. While the 3D framework was not a part of the conception of either the MSIKA project or the gender training, the co-creation approach produced valid results and allowed the trainees to incorporate issues of local importance focusing on the human rights of the participants. Closer attention to diversity of traditional local knowledge and worldviews would have allowed for more robust grounding of the concepts in the local context.

\subsection{CASE STUDY 3: Household Edible Insect Farming to Boost Food Security in Guatemala}

A woman in the coffee-growing western highlands of Guatemala bends over a small farm located inside her house. Not many people have a farm inside, but this mother of two is part of a training program organized by MealFlour. She tosses in vegetable scraps and watches the edible mealworms (Tenebrio molitor larvae) wriggle around. In recent months, she has swapped expensive nutritional supplements for a protein-rich flour made from toasted gusanos de harina, which she adds to pancakes to feed her family.

Increased consumption and production of edible insects has been touted as one way to sustainably address food insecurity, drawing on a long history of insect consumption across the globe that continues today. Guatemala is no exception, where leaf cutter ants (zompopos de Mayo) are considered a delicacy by some, roasted or fried with butter and served with tortillas and lime. Insects are nutrient-dense, containing ample protein, essential amino acids, minerals, some vitamins, and even dietary fiber [36-38]. From an environmental standpoint, insects require less land, feed, and water than traditional livestock [39], while emitting substantially fewer greenhouse gases [40]. They require limited technology and labor to farm, making it a feasible task for people of all socioeconomic and educational backgrounds.

The Project. MealFlour aims to "promote better nutrition through the sustainable farming of protein-rich mealworms". Since its initiation, MealFlour has collaborated with three Guatemalan organizations to address chronic malnutrition, food insecurity, and protein deficiency, which are problematic across the country. MealFlour trains women to build and operate low-labor, in-house mealworm farms so that families will have a more affordable, stable source of protein year-round. As skill and production increases, mealworms could be sold to broader markets, helping lift families out of poverty. MealFlour specifically addressees SDG 2 (hunger), SDG 1 (poverty) and SDG 5 (gender equality), and SDG 13 (climate action) [4].

To initiate an inaugural train-the-trainer program, MealFlour brought together community leaders, health workers, and teachers in several food insecure communities. Participants completed a six-month training program (which included classes, home visits, and focus groups) covering basic nutrition (with an emphasis on protein), insect flour in a balanced diet, and how to farm. Bilingual teachers (in Spanish and Mayan language) provided the training. Local partners continue to monitor and evaluate the program, adding both accountability and transparency.

In February 2019, MealFlour and local partners concluded the first train-the-trainer program, whereby 19 women were trained to become mealworm ambassadors, prepared and empowered to go on to teach others to farm. The second round of trainings was halted due to COVID-19, but each ambassador will eventually train at least three others. 
Applying the 3D Framework. At the heart of the MealFlour program is an effort to increase wellbeing. People in target communities live and work under conditions that limit their rights; they do not have social protections or guarantees for a basic standard of living, education, food, shelter, or healthcare. Many participants are illiterate or only attended the initial years of primary education, due in part, to linguistic barriers in the formal education system. Moreover, coffee plantations are notorious for exploitative labor practices. By learning to farm insects at home, participants may gain autonomy over food production, access, and finances. While, human rights framing was not an explicit driver of this work, the project is congruent with a human rights approach.

The impetus for and initial formation of MealFlour did not involve local participants; however, once established, the train-the-trainer program was organized with local partners by collective consensus. MealFlour relies heavily on these organizations, which share the same overarching objectives, and have longstanding relationships and established trust with the communities. Moreover, a "call for volunteer participation" at the onset of this program facilitated liaising with community leaders. Undoubtedly, some elements of hierarchy still exist, but MealFlour has labored to work in partnership with trainees and local leaders; concerns and suggestions are fully welcomed, and the project has made linguistic and other adjustments to ensure equal access.

Women are an essential focus of MealFlour's work given their traditional role in food production and preparation. The migration of men, along with traditional gender roles, leaves women responsible for household management, childcare, cooking, and farming. Many also take on roles typically held by men, such as managing coffee plantations and financial saving. MealFlour is mindful of these gender dynamics, after learning quickly that their training calendar must be adjusted to align with the coffee calendar. Trainings risk burdening already overfilled schedules, but women have reported that the trainings add meaning to their lives and provide a space for bonding in community and empowerment. Many participants are widows, heads of households, or single mothers living without support. The gathering of women (and their sons and daughters) to learn a new skill serves as a mechanism to push trainees beyond insect farming into structural themes of resistance and resilience whereby the main protagonists are local women. MealFlour trainings reinforce self-esteem and the visibility of women in decision-making roles to support wellbeing, and the nutritional health of the home. It is unclear how the program may disrupt, conform to, or push against existing gender roles in the long-term.

The Indigenous people of Guatemala retain a strong sense of connection with nature that underpins the worldview of communities, where knowledge is passed orally by elders to younger generations and bridges generations. The MealFlour project is contextualized by this local knowledge and a culture of eating insects. Women participants bring with them a wealth of knowledge about edible insects, plants, medicines, and other natural goods that are important to the community. During trainings, this knowledge is prioritized. MealFlour asks ambassadors to share experiences and guide discussion regarding insect consumption, farming, and food preparation. While mealworms are a new insect food in these areas, Indigenous knowledge of other insects, food safety, and food processing has been incorporated into the program through a two-way learning process that enriches both the MealFlour team and the participants.

Conclusion. The initial train-the-trainer program was largely successful. A survey of ambassadors regarding fundamental farming knowledge revealed a correct response rate between $85-100 \%$ per topic, indicating efficacy of the implemented curriculum. Participants also reported that they found the curriculum to be useful and applicable, expressing general satisfaction with the training.

Lessons can be learned from the train-the-trainer pilot. First, while ambassadors were engaged in the train-the-trainer project throughout, they were not arbiters or designers. Their feedback at this stage is crucial in shaping and driving the project using more Indigenous knowledge and community participation moving forward. Second, more efforts to provide information in the local language (Mam) using culturally appropriate descriptions are required. The curriculum must be modified and better contextualized to the sociocultural environment, specifically related to foods that are available. 
Additionally, ambassadors need more capacity and training on monitoring and evaluation instruments so that they can properly collect data.

MealFlour faces challenges with productivity given variable climates across Guatemala and the low-tech, low-cost structure of their home farms. Future initiatives should consider multiple species and adaptation for different climates and engage in further acceptability studies, while involving participants in farm and protocol designs [41]. Despite these challenges, it is apparent that in reclaiming and promoting insects as a valuable food resource, along with sensitization and education efforts, new initiatives like MealFlour may have the potential to contribute to community empowerment and improved food security.

\subsection{CASE STUDIES 4 and 5: Restoring Indigenous Foodways in Peru and Aotearoa New Zealand}

In case studies four and five, I show how two Indigenous communities in two corners of the world, the Quechua community of Choquecancha in the highlands of Peru, and the Papatūānuku Kokiri Marae, an urban Māori community in Aotearoa New Zealand, are restoring their Indigenous foodways offering pathways for a more sustainable, equitable, and just food system.

Food is one of the most basic human needs and a human right. For the Quechua and Māori, food has meaning beyond just sustenance as food intertwines with their culture, health, and wellbeing [42]. However, since colonization, Indigenous peoples living in settler-colonial societies such as Māori and Quechua have had to endure social and environmental injustices [11]. Examples, include the appropriation of their ancestral lands, limiting their access to 'traditional' foods or foodways, and the imposition of industrial foods tainted with pesticides into their diets threatening their lives [11]. Although the rights of Indigenous peoples to their lands, territories, and resources are enshrined in the United Nations Declaration on the Rights of Indigenous Peoples [23]. Indigenous communities continue to struggle to get their right to culturally appropriate food recognized [43]. Still, these communities continue to resist food injustice by revitalizing their foodways. The two examples discussed here are cases in point.

The Papatūānuku Kokiri Marae in Aotearoa New Zealand. The Papatūānuku Kokiri Marae is a self-sustainable urban marae (communal space) in the heart of Auckland City, established in 1984 with a twofold aim as expressed by Hinemaru Ropati "to service the needs of Māori from children, to youth, to elders in South Auckland, and to recover the knowledge of our ancestors about sustainable kai (food) production to feed ourselves, families, and communities" [44].

In 2012, during a workshop about how to grow Māori food at the Papatūānuku marae, I met Hinemaru Ropati, Leonel Hotene and his wife Valerie Teraitua. We worked closely ever since in supporting the aspirations of Indigenous peoples to be food-secure and to preserve cultural knowledge about foodways. The Papatūānuku Kōkiri Marae grows seven varieties of kūmara (sweet potatoes), and an array of fresh vegetables using the teachings of maramataka (Māori lunar calendar) and agricultural rituals. As Leonel Hotene pointed out, "all elements in our food garden, such as seeds and plants, have spirits, and this is why it is important to do a karakia (prayer) to ask and obtain consent from our non-human kin to work on the food garden" [45]. In a conversation with Leone Hotene, he reasoned that in industrial food production "the spiritual element is missing, the spiritual connection is missing in foods, the spiritual connection between us as people, to the land and the atuas (spiritual beings), and sadly to the detriment of our peoples". Restoring this human-nature-spiritual relation is precisely what the Papatūānuku Kōkiri Marae is doing through collective agency and sheer hard work. This urban marae offers a range of community events and meetings, including youth leadership programs, gardening of traditional Māori seeds, fresh fruit, and vegetables, cooking classes, community dinners, among other activities. In this community, both men and women have vital roles to play, ranging from growing food crops, to cooking and teaching about Indigenous agroecological practices. I observed that the team at the Papatūānuku Kōkiri marae strives to achieve physical and spiritual wellbeing that comes with community engagement with the land, ancestral traditions, techniques for a healthier and sustainable way of living, and staying grounded in their roots and cultural identity 
The Quechua Community of Choquecancha in Peru. The Quechua community of Choquecancha is nested in the highlands of Peru located at $3150 \mathrm{~m}$ or 10,334 feet above sea level. This small village has a population of approximately 250 people [11]. In 2012, I lived deep in the rural highlands of Peru, where I had the opportunity to form relationships and food forage with Quechua leaders (Petronila Quispe, Sonia Tito and Maria Quispe) from the Choquecancha community. This activity became a tradition for us, and marked the beginning of our research partnership on food and seed sovereignty. I observed that the people of Choquecancha, especially the women, are skilled textile weavers and experts in wool dying techniques. The people are proud of their Andean heritage; their main source of livelihood is farming maize, native potatoes, and other Andean crops and livestock, mainly for subsistence.

Applying the 3D Framework. This work was realized within an Indigenous framework that is highly congruent with both human rights and gender equity principles. The individual and collective rights of Indigenous peoples provide a space for advocacy and voice for Indigenous peoples and for inclusion of Indigenous ways of knowing. Similarly, gender equity is well-aligned with the Indigenous traditions studied. Both men and women work in the land together and largely use traditional agroecological practices which sustain rich agrobiodiversity, wildlife and ecosystem services such as water. For example, the cultural values of yanantin and mansitin ("principle of 'duality or complementation'") are rooted in their everyday life practices. In an attempt to explain them, Petronila Quispe [46] pointed to the way they cultivated seeds together. Indeed, I observed that both men and women carefully select both male and female seeds for pollination. Then, the men ploughed the land, and together men and women planted the seeds. She added that "this process ends in the culmination of the harmonious experience of complementarity" [42]. Therefore, it is understood that yanantin and mansitin are principles that embody the transmission of knowledge relating to agricultural practices, where the roles of women and men complement each other. In terms of both, human rights and gender, Indigenous approaches go beyond mere alignment to bring out valuable insights that expand the meanings and possibilities of these concepts for all.

Conclusion. These two examples elicit how Quechua and Māori peoples' enacted practices of autonomy, self-sufficiency, community empowerment, gender equity, and solidarity, framing an 'Indigenous food sovereignty framework' that goes beyond the human rights-based approach to food and emphasizes their long-standing sacred responsibilities to nurture healthy, interdependent relationships with the land, plants and animals that provide them with food [42]. We are currently experiencing an Indigenous food sovereignty movement sweeping across Oceania, North America and Latin America, as tribal communities are fighting and organizing to reclaim and regain their traditional food systems as a means of improving health and promoting culture [47]. In New Zealand, there is a wide range of māra kai (food gardens) and training on free, prior and informed consent among Māori people when engaging with academic, businesses and community-based projects. In the rural highlands of Peru, Quechua communities are strengthening their seed saving initiatives and we continue working towards educating the youth about biodiversity and biocultural heritage preservation.

The revitalization of Indigenous agroecological practices entrenched in their foodways have implications not only for achieving SDG2 (hunger), but it also contributes to holistic wellbeing and therefore has an impact in the achievement of the broader interrelated 17 SDGs. The examples of Quechua and Māori restoration of their Indigenous foodways provide a pathway towards the transformation of food systems from the dominant calorie counting diet to one focusing on physical and spiritual wellbeing that is often overlooked in academia, law and policymaking.

\subsection{CASE STUDY 6: Healthy Air and the Role of Women in Climate Change Response in Côte d'Ivoire}

According to the International Development Research Centre (IDRC) of Canada, urban air pollution, inside and outside homes, poses a major health and environmental problem in the world and in Africa in particular, where it is associated with economic activities, transportation and the use 
of biomass for cooking [48]. In Côte d'Ivoire, $73 \%$ of the population uses biomass (charcoal or wood) for cooking [49].

The Project. The AIR SAIN project d'Ivoire linked to the 2018 Local Conference of Youth in Côte $d^{\prime}$ Ivoire (LCOY) [50] illustrates the essential inclusion of women to address health and environmental issues while using cookstoves in developing countries. As part of the Chair Pol project funded by the IRDC and implemented by the Eco-health community in four countries (Benin, Burkina Faso, Ivory Coast and Senegal) [48], the project aimed to develop adaptation strategies in West African urban areas for the benefit of municipalities and communities, in order to contribute to the protection of the environment, the health of the population, and guarantee social and gender equity.

Applying the 3D Framework. While, human rights were not explicitly mentioned in the project objectives, the AIRSAIN project contributed to the realization of the right to live in a healthy environment while promoting the use of cleaner cookstoves. The African Charter of Human and People's Rights, 1981 is the first international treaty to recognize the human right to a healthy environment [51]. The Ivorian constitution in 2000 and 2016 also reaffirmed the importance of preserving the climate and a healthy environment for future generations, and recognized the right to a healthy environment for everyone throughout the national territory (Article 27).

In Yopougon, one of the most crowded municipalities of Abidjan, the measured levels of PM2.5 indoor emission concentration from domestic cookstoves, were 1.6 to 28 times higher than the standards recommended by the World Health Organization, according to Professor Yoboue Véronique, the head of the project. It is estimated that using one clean cookstove could contribute to saving 1.7 hectare of forest per year, and 3 tons of $\mathrm{CO}_{2}$ sequestered per year [52]. "Although, they may seem to be two very different issues, climate change and air pollution are closely interlinked, and by reducing air pollution we also protect the climate" [53]. In April 2020, during the restrictions imposed to curb the spread of Covid-19, there was a $17 \%$ reduction in global $\mathrm{CO}_{2}$ emissions [54]. Using clean cookstoves will reduce indoor pollution, improve health and reduce deforestation and its impact on climate change and contribute towards the realization of SDG 7 (affordable and clean energy), and SGD 13 (climate action).

The project focused on empowering women to guarantee social and gender equity. Women experience unequal access to resources and decision-making processes. For example, many of the climate change strategies and networks do not include women as actors and beneficiaries of adaptation and mitigation responses. It is thus important to identify gender-sensitive strategies that respond to these crises for women [55]. The AIR SAIN project focused on women but did not challenge gender norms. However, it managed to integrate the work of both men and women (SDG 5 on gender equality). In November 2018, 100 women from Yopougon received improved cookstoves and AIR SAIN conducted an awareness campaign for women, men, and stakeholders such as municipal leaders. During the 2018 LCOY conference in Abidjan, women leaders and women working on environmental protection during the "Quand j'y étais" program for the Young African Leaders Initiative (YALI) shared their experiences.

The project did not aim to examine Indigenous knowledge. However, the distribution of clean and sustainable cookstoves in Abidjan city, emphasized the impacts of traditional habits in an urban context. According to the World Health Organization, traditional cookstoves are linked to 1.6 million deaths per year due to indoor pollution [56] high fuel consumption (wood and charcoal), high emission of toxic fumes during cooking leading to health problems such as pneumonia, asthma, bronchitis, rhinitis, and eye pain. The distribution of clean and sustainable cookstoves inspired by traditional techniques help reduce health impacts and mortality according to the eco-health approach. Moreover, it contributes to energy efficiency and reduces energy consumption (SDG 11 on Cities and Sustainable Communities and SDG 12 on Responsible Consumption and Production). In the context of rapid urbanization of African mega-cities, traditional knowledge and technologies is a cultural reference for communities, part of their identity that need to adapt to local contexts for a better ownership and appropriation.

Conclusion. The AIR SAIN project is the prototype of an inclusive multi-disciplinary development and research project. While, contributing to improving the right to a healthy environment along with 
many SDGs, the project empowered women in relation to air pollution, health, clean energy and climate change, while facing challenges using traditional practices in the city. Taking into account the impact of pollution on human rights, and the recognition of the right to a healthy environment internationally will be helpful [57].

\subsection{CASE STUDY 7: COVID-19, Income Generation and Food Security in Sri Lanka}

This case study describes an income generation project launched by Sarvodaya, the largest community development organization in Sri Lanka, during the COVID-19 outbreak to increase food security in the country.

About Sarvodaya, its History and Mission. The mission of the Sarvodaya Sramadana Movement (Sarvodaya-"awakening for all") is three-fold: (a) creating a conflict-free society with no poverty and no affluence; (b) uplifting and empowering the most disadvantaged people in Sri Lanka; and (c) Total Awakening and Wellbeing of All (individuals, family, village, nation, and the world) on every plane (spiritual, moral, cultural, social, economic and political) [58]. Established over 50 years ago in just one village as an education program and assisting with self-help projects, the movement has expanded to service more than 15,000 villages. Over the years, thousands of young men and women have learned how to organize themselves to meet ten basic human needs, ranging from a clean and adequate drinking-water supply to housing and sanitation, communications facilities, energy supplies, education and ways of satisfying spiritual and cultural needs.

After the three decade-long ethnic conflict ended in Sri Lanka, Sarvodaya extended its work to include peace building and conflict resolution. It also focuses on providing appropriate technology and programs for children at risk, elders and those with disabilities. Its sister organizations address women's rights, development finance and empowering marginalized sections of society, including disabled people, the elderly and street children. Sarvodaya Women's Movement (SWM), established in 1987, has taken the lead in livelihood programs, empowerment and gender issues in Sri Lanka [59].

The Project. While, Sri Lanka managed the outbreak of COVID-19 successfully with only 3155 positive cases and 12 deaths by taking strict measures such as imposing a curfew, closing its international airport, requiring strict quarantine measures and aggressive contact tracing [60-63]. The economic impact was felt by many people across the country especially those who were reliant on tourism and those who were in the informal employment sector. To help ease food insecurity of those especially affected and to help them generate an income, Sarvodaya designed a project to encourage people to grow food crops in their gardens (on a larger scale where possible), to address the shortage of vegetables and fruits in the local market. Sri Lanka is blessed with favourable weather conditions throughout the year so growing food crops is not restricted to certain seasons. Although, seasonal variation is seen in relation to some crops. As the largest community development organization in the country with its presence in over 15,000 villages, Sarvodaya took this opportunity to generate income leading to food security.

Despite the simplicity of the project, Sarvodaya faced several challenges, including: non availability of an efficient distribution network for agricultural products; low profit margin; inadequate crop diversification; scarcity of improved and high quality Indigenous varieties of plants/seeds; access to modern technology; a lack of adequate water, high cost of labor and scarcity of capital. Climate change which has given rise to both droughts and floods was identified as a larger and more pervasive challenge to the long-term success of the project.

Objectives. The objectives of the project included: establishing a mechanism to streamline agro-businesses within the organization; employing workforce on agro-related activities while utilizing physical resources of Sarvodaya; creating income generating opportunities in districts and farms, extending the home garden model to communities to ensure food security of households and creating income generating opportunities and making food distributing channels within the organization with new market opportunities. Broader and more long-term objectives of the project included 
introducing new technology in agriculture; fulfilling Sustainable Development Goals; and linking with the agro-tourism program of Sarvodaya.

Applying the 3D Framework. Although no human rights language was used in describing the project, the project clearly seeks to improve human rights especially, the rights to food [64], health [65], a livelihood [66], an adequate standard of living [65], gender equality [22], and on a broader level, the right to development [67]. The project did not involve Indigenous peoples [68], but one of the challenges that the project encountered was the lack of high quality Indigenous varieties of plants and seeds. Its reference to SDGs is significant as this project has implications for several SDGs: SDG 1 (poverty); SDG 2 (hunger); SDG 3 (health and wellbeing); SDG 5 (gender equality); SDG 8 (decent work); and SDG 10 (reducing inequality) [4].

While, it is not clear from the information provided how decisions were made and what kind of information was provided to the community and how, Sarvodaya has a long history of decentralized decision-making procedures involving district coordinators, community leaders and community members at the village level and it is highly unlikely that they deviated from their standard procedure.

Similarly, this project did not target a specific group. However, if a gender equality approach was adopted, the project could have provided special financial assistance to women, provide them with information about accessing seeds and plants, as well as successful planting and irrigation methods. The project could have benefited from their knowledge too. This project did not result in a violation of rights or the need to balance competing rights. On the contrary, if implemented properly, the project can lead to the improvement of socio-economic rights.

Since this project is ongoing and recent, no data is available on the impact of the project on women's work specifically. While, the project targeted both men and women, it is likely that in the long run, the burden of maintaining and continuing home gardens would fall on women who are more likely to be stay-at-home mothers or part time workers [69]. While, it is not clear from the information provided how this project will impact gender dynamics within, and outside, the household, the mandate of the Sarvodaya Women's Movement's is to empower women, improve their position within and outside the household and make them financially independent [59].

Sarvodaya is keen to revive and apply Indigenous and/or local knowledge in relation to agriculture and sustainability. Sri Lanka has an intricate network of ancient irrigation systems and historically been self-sufficient in agriculture as recognized by Judge Weeramantry, then Vice President of the International Court of Justice, in his discussion on sustainable development [70]. While, the ancient irrigation network of reservoirs and tanks is still in existence, ancient wisdom, traditional knowledge and traditional seed varieties [71,72] have, unfortunately, been overtaken by modernization and mechanized agriculture.

Conclusion. Sri Lanka has transitioned from a predominantly rural agricultural economy to a more urbanized manufacturing and service-based economy [73], even though the majority of Sri Lankan still live in rural areas. Sarvodaya has made remarkable progress in empowering community members, especially women, at the village level. This project was started during COVID-19 to improve food security and increase the income of community members. While, the project did not use language related to human rights, gender equality and local knowledge, it does contribute to the enjoyment of many rights, promotes gender equality and seeks to utilize Indigenous seeds, plants and knowledge. By adopting the $3 \mathrm{D}$ framework developed here, the project can be improved further by engaging the community, and consulting with them to address the challenges that have come up.

\section{Part 3: Lessons Learned}

Of the six case studies, three were explicitly framed in terms of one the 3D critical dimensions -gender, human rights, and Indigenous and local knowledge. Two employed gender approaches (Côte D'Ivoire and Malawi) and one dual-country case used a framework of Indigenous knowledge (Peru and New Zealand). None of the cases used more than one dimension, and three cases, while aligned with one of the dimensions, did not make explicit reference to that dimension as a core principle or 
value. Meanwhile, all researchers and collaborators opined that the 3D model had the potential to enhance theory, practice, impact and value of the project.

Interestingly, two cases that did not highlight rights, gender or Indigenous knowledge in an explicit way (Sri Lanka and Guatemala MealFlour) had strong affinity and alignment with all three dimensions. They were implicitly aligned with these principles and therefore directly advanced the notion of integration. This underscores the potential of using explicit frameworks to strengthen and complete implicit agendas. The clarity of purpose and programmatic adjustments that would ensue could enhance impact and foster more rapid spread and adaptation of transformative practices.

As the three dimensions are conceptually congruent and complementary to each other and with core sustainability concepts, there were few or no concerns that adding one or more of these dimensions would contradict, complicate or undermine the projects. On the contrary, these new ideas were welcomed by researchers and partners. The exception to this was expression of concern that gender-empowerment approaches could be viewed as unacceptable by the community. This concern was raised within a gender-based program, and it could be argued that the 3D approach would have been a more acceptable frame than a gender lens alone. A further shortcoming of the case review approach was that the questions did not take an explicitly intersectional approach, so the dynamics of double burden, and layered vulnerabilities were not addressed. This was due, in part, to the retrospective nature of this preliminary exploration. In the next iteration of the 3D model, we feel it is essential to talk about the lived experience of marginalized and stigmatized groups in all mainstream development efforts.

All case studies found it relatively easy to link their work to the SDGs, at least in a nominal way, even if another framework (such as Indigenous worldview or human rights) was predominant. While, there are important distinctions and nuances among the sustainability approaches, this phenomenon suggests that the SDGs will be the central focus of law and policy for the coming decade and beyond. The 3D approach makes it possible to expose and reconcile tensions between sustainability strategies (the SDGs in particular) and at the same time make them more effective with 3D thinking. It also suggests that the SDGs could evolve into the most encompassing and complete framework, if rights, gender, and local and Indigenous knowledge are integrated fully into all aspects of the SDGs.

The 3D model, proposed here, outlines an effective way to de-center economic metrics that fail to encompass justice, that mis-measure and misrepresent the lived experience of gender in society, and that discount or erase particular local and Indigenous history and ways of knowing. The proposed approach can bring much-needed balance in perspective to theory and practice, in law and all fields that are engaged in sustainable development and human thriving. This approach is a step toward centering and sustaining the wellbeing and thriving of humans, all life forms, and the natural and built environment.

Given the degree to which these three dimensions are already codified and documented in law and other fields, there is great potential to develop legal and policy strategies to make 3D thinking a reality in sustainable development. Using the right tools, these principles could be carried through from needs assessment, to project design, advocacy, implementation, evaluation and scale-up. This would be a step towards the adoption of a more holistic approach to directing efforts toward the realization of SDGs at local, regional, national, and global levels.

In summary, in a world where our environment is the floor or foundation of a sustainable future, we have posited that human rights, gender equity and Indigenous and local knowledge are three essential, complementary and congruent dimensions of analysis. Despite this, they have not been adequately and routinely integrated in sustainability frameworks. These three dimensions overlap, and they each have unique and essential contributions. While, recognizing the importance of other disciplines, human rights and the law provide key elements, such as tools for redress, as well as legal and policy strategies for implementation, accountability, consistency, and impact assessment. Human rights, gender sensitive approaches, and Indigenous knowledges and worldviews, have value individually, and they build on each other-with productive tensions but mostly harmoniously and 
synergistically-to aid local communities, regions, nations and the world to achieve a more just and enduring quality of life, while sustaining the earth for future generations.

Author Contributions: L.D.B., S.A., V.J.S., C.I.C, M.H., A.S., and M.J.P.H. led the conceptualization and design of the manuscript. V.J.S., L.D.B, and M.J.P.H. planned and coordinated the workshop that was the genesis of this work; all authors (excluding A.M.) attended the workshop. L.D.B., S.A., V.J.S., C.I.C., M.H., A.S., and M.J.P.H. contributed to theory development, methods, analyses, and fine-tuning. S.A., V.J.S., C.I.C., M.H., A.S., M.J.P.H., and A.M. wrote and developed case studies for the manuscript. All authors contributed to final revisions. All authors have read and agreed to the published version of the manuscript.

Funding: This research received no external funding.

Acknowledgments: The authors acknowledge the African Studies Program and the Global Health Institute at UW-Madison, for respectively providing the generous Young African Leaders Initiative-Mandela Washington Fellowship travel award to Marie Josée Paula Houénou and for hosting the International Gender and Climate Change Workshop in September 2019. We also acknowledge the 4W Food, Indigeneity and Gender circle at UW-Madison. Special thanks to the knowledge holders, small holder farmers, community leaders, and collaborators in Aotearoa New Zealand, Côte d'Ivoire, Guatemala, Malawi, Peru, and Sri Lanka for sharing their wisdom and insights to the creation of the case studies. We are grateful to our colleagues around the world who make this work, and a more sustainable world, possible.

Conflicts of Interest: The authors declare no conflict of interest.

\section{Appendix A}

Table A1. The 3-D Model and Common Sustainability Approaches.

\begin{tabular}{|c|c|c|c|c|}
\hline- & SDGs & De-Growth & Agroecology & Planetary Health \\
\hline Key Principles & $\begin{array}{l}17 \text { inter-related goals with } \\
\text { sub-goals and metrics. } \\
\text { Food, water, education, } \\
\text { health, gender equity, } \\
\text { climate change, etc. } \\
\text { Based on premise that } \\
\text { growth and environmental } \\
\text { sustainability can work in } \\
\text { alignment. } \\
\text { Begins to integrate goals } \\
2019 \text { with articulation of } 6 \\
\text { clustered } \\
\text { "transformations" related } \\
\text { to education, health, } \\
\text { energy, food and water, } \\
\text { cites, and the digital } \\
\text { revolution. }\end{array}$ & $\begin{array}{l}\text { Challenges the idea that } \\
\text { growth is sustainable or } \\
\text { necessary for human and } \\
\text { environmental thriving. } \\
\text { Seeks to redistribute } \\
\text { resources and downscale } \\
\text { production and } \\
\text { consumption. } \\
\text { Units of production and } \\
\text { metabolism of resources } \\
\text { will be both smaller and } \\
\text { different. } \\
\text { Aims to distribute both } \\
\text { assets (land and resources) } \\
\text { and risks (pollution, waste, } \\
\text { resources insecurity) more } \\
\text { equally and more justly. }\end{array}$ & $\begin{array}{l}\text { Draws on the sciences as } \\
\text { defined by the academy } \\
\text { and traditional ecological } \\
\text { knowledge. } \\
\text { Aims to meet human needs } \\
\text { by recycling biomass in the } \\
\text { field, regenerating soil, } \\
\text { diversifying the } \\
\text { agroecosystem, mimicking } \\
\text { ecological processes, while } \\
\text { preserving social processes. } \\
\text { Uses of heritage seeds, } \\
\text { integrated pest } \\
\text { management, and avoids } \\
\text { external inputs. } \\
\text { Vision is based on small } \\
\text { scale farming that is } \\
\text { feasible in terms of } \\
\text { efficiency and resilience. } \\
\text { Scale is achieved through } \\
\text { spread of smaller units. }\end{array}$ & $\begin{array}{l}\text { Relates human activity } \\
\text { and health to } 9 \text { natural } \\
\text { processes that regulate the } \\
\text { stability of the earth } \\
\text { system. } \\
\text { Metrics and boundaries } \\
\text { are identified: ozone } \\
\text { depletion, bio-diversity, } \\
\text { chemical pollution, climate } \\
\text { change, water systems, } \\
\text { nitrogen and phosphorus } \\
\text { levels, aerosol load. } \\
\text { Focus is on the health not } \\
\text { just of people or } \\
\text { populations but of human } \\
\text { civilization and the state of } \\
\text { the natural systems upon } \\
\text { which it depends. }\end{array}$ \\
\hline References & $\begin{array}{l}\text { The Sustainable } \\
\text { Development Goals } \\
\text { Report, } 2019 \text { [13] }\end{array}$ & Akbukut et al., 2019 [14] & $\begin{array}{l}\text { Gliessman } 1988 \text { [14] } \\
\text { Altieri and Toledo, } 2011 \\
\text { [15] } \\
\text { Einbinder et. Al., 2019 [74] }\end{array}$ & $\begin{array}{l}\text { The Lancet Planetary } \\
\text { Health, } 2017 \text { [18] } \\
\text { Myers and Frumkin, } 2020 \\
\text { [18] }\end{array}$ \\
\hline $\begin{array}{l}\text { Human Rights } \\
\text { Dimension }\end{array}$ & $\begin{array}{l}\text { Human rights correspond } \\
\text { with SDGs } \\
\text { SDGs are seen as a } \\
\text { pre-condition for } \\
\text { realization of rights } \\
\text { SDGs rely more heavily on } \\
\text { a development or } \\
\text { economic logic than } \\
\text { rights-based imperatives. } \\
\text { Human rights as a means } \\
\text { and end could strengthen } \\
\text { SDGS and reconcile } \\
\text { differences with other } \\
\text { models. }\end{array}$ & $\begin{array}{l}\text { De-growth focus on equity } \\
\text { is aligned with human } \\
\text { rights principles, however } \\
\text { it tends to try to solve a } \\
\text { problem within economics } \\
\text { with alternative economics. } \\
\text { A more explicit } \\
\text { rights-based process could } \\
\text { strengthen the } \\
\text { effectiveness and political } \\
\text { feasibility of de-growth } \\
\text { approaches. }\end{array}$ & $\begin{array}{l}\text { Human rights is implicit in } \\
\text { the agroecological } \\
\text { emphasis, on community, } \\
\text { harm avoidance, and } \\
\text { meeting subsistence needs. } \\
\text { It centers its work in the } \\
\text { sciences -and inclusive } \\
\text { science that takes in } \\
\text { traditional knowledge is } \\
\text { deeply aligned with } \\
\text { human rights. } \\
\text { While demonstration is the } \\
\text { key to scale, human rights } \\
\text { principles might enhance } \\
\text { practice and be a good tool } \\
\text { for advocating scale up as } \\
\text { a moral imperative. }\end{array}$ & $\begin{array}{l}\text { The planetary health } \\
\text { rationale is articulated in } \\
\text { terms enlightened } \\
\text { self-interest for humans } \\
\text { and also references the } \\
\text { rights of human } \\
\text { civilization. } \\
\text { As this theory develops a } \\
\text { more explicit and legal } \\
\text { analysis of how human } \\
\text { rights support planetary } \\
\text { health goals would be } \\
\text { useful. }\end{array}$ \\
\hline
\end{tabular}


Table A1. Cont.

\begin{tabular}{|c|c|c|c|c|}
\hline- & SDGs & De-Growth & Agroecology & Planetary Health \\
\hline $\begin{array}{l}\text { Gender Equity } \\
\text { Dimension }\end{array}$ & $\begin{array}{l}\text { Includes gender as one } \\
\text { goal, recognizes linkages } \\
\text { to others but not fully } \\
\text { integrated. } \\
\text { Does not include guidance } \\
\text { on how to include women } \\
\text { in leadership } \\
\text { Does not address the full } \\
\text { range of gender identities }\end{array}$ & $\begin{array}{l}\text { De-growth approaches are } \\
\text { not explicit about gender } \\
\text { equity though the overall } \\
\text { equity claim does imply } \\
\text { better quality of life for } \\
\text { women. } \\
\text { As complex developed } \\
\text { and mechanized societies } \\
\text { are critiqued a gender lens } \\
\text { is useful and important to } \\
\text { ensure that labor is } \\
\text { re-arranged equitably and } \\
\text { that devolution does not } \\
\text { have the unintended } \\
\text { consequence of creating or } \\
\text { reintroducing inequitable } \\
\text { division of labor. }\end{array}$ & $\begin{array}{l}\text { This approach tends to } \\
\text { respect and give voice to } \\
\text { the knowledge and agency } \\
\text { of women. } \\
\text { Some gender } \\
\text { empowerment is implicit } \\
\text { in this model. } \\
\text { Women are beneficiaries of } \\
\text { the self-reliant approach; it } \\
\text { could benefit from explicit } \\
\text { acknowledgement of the } \\
\text { equality of women. } \\
\text { Attention to equitable } \\
\text { division of labor in the } \\
\text { household and community } \\
\text { is important for this } \\
\text { approach to achieve its full } \\
\text { potential. } \\
\text { Promotion of women in } \\
\text { STEM is also needed. } \\
\text { Does not address the full } \\
\text { range of gender identities }\end{array}$ & $\begin{array}{l}\text { Planetary health is } \\
\text { gender-informed to the } \\
\text { degree that it subsumes } \\
\text { fields such as global health, } \\
\text { eco-health and one health, } \\
\text { which all have only partial } \\
\text { articulation or inclusion of } \\
\text { gender equity. } \\
\text { Gender equity in STEM } \\
\text { fields and planetary health } \\
\text { leadership is a critical first } \\
\text { step. } \\
\text { Overall the link between } \\
\text { planetary health metrics } \\
\text { and other more human } \\
\text { centered and place-based } \\
\text { metrics is still being } \\
\text { developed. Attention to } \\
\text { gender-inclusive } \\
\text { approaches to selection of } \\
\text { metrics and disaggregation } \\
\text { of data by sex would be } \\
\text { important first steps. }\end{array}$ \\
\hline $\begin{array}{l}\text { Indigenous and } \\
\text { Local Knowledge } \\
\text { Dimension }\end{array}$ & $\begin{array}{l}\text { Indigenous communities } \\
\text { are mentioned in SDGS in } \\
\text { relation to increasing food } \\
\text { productivity of small farms } \\
\text { and access to education for } \\
\text { Indigenous children. } \\
\text { Many SDGs are aligned } \\
\text { with Indigenous values. } \\
\text { Indigenous knowledge } \\
\text { that supports integration } \\
\text { and holistic } \\
\text { understandings could } \\
\text { strengthen SDGs in terms } \\
\text { of clarity, meaning } \\
\text { purpose, and related } \\
\text { actions. }\end{array}$ & $\begin{array}{l}\text { Local and Indigenous } \\
\text { knowledge are important } \\
\text { resources for de-growth } \\
\text { approaches. } \\
\text { While some de-growth } \\
\text { approaches do draw on } \\
\text { practices, or specific } \\
\text { cultural articulations of the } \\
\text { good life, there is not a } \\
\text { systematic effort to center } \\
\text { local and Indigenous } \\
\text { knowledge in the } \\
\text { de-growth } \\
\text { movement-which is more } \\
\text { focused on critiquing the } \\
\text { economic status quo. } \\
\text { De-growth approaches } \\
\text { would be strengthened by } \\
\text { using this knowledge as a } \\
\text { foundation for alternative } \\
\text { economics and } \\
\text { conceptualizations of } \\
\text { value and quality of life. }\end{array}$ & $\begin{array}{l}\text { This model embraces } \\
\text { Indigenous and local } \\
\text { practices. } \\
\text { It could benefit from fuller } \\
\text { inclusion of Indigenous } \\
\text { knowledge, including } \\
\text { social, philosophical ways } \\
\text { of knowing as well as } \\
\text { Indigenous science. }\end{array}$ & $\begin{array}{l}\text { Indigenous ways of } \\
\text { understanding the } \\
\text { relationships between } \\
\text { people, the land and life } \\
\text { can inform the nascent } \\
\text { attempt to deal with these } \\
\text { ontological concepts } \\
\text { within planetary health. } \\
\text { Planetary health is } \\
\text { grounded in scientific } \\
\text { boundaries on the one } \\
\text { hand, and the desire to } \\
\text { perpetuate the whole of } \\
\text { human civilization on the } \\
\text { other. There is not yet a } \\
\text { clear articulate of what it } \\
\text { means at place-based and } \\
\text { local scales. Local and } \\
\text { Indigenous knowledges } \\
\text { (along with more input } \\
\text { from the social sciences } \\
\text { and humanities) can help } \\
\text { it to articulate its aims in } \\
\text { terms of survival and } \\
\text { preservation in more } \\
\text { place-based historically } \\
\text { contextualized ways. }\end{array}$ \\
\hline
\end{tabular}

\section{References}

1. Stull, V.; DiPrete Brown, L.; Houenou, M.J. Report of the International Gender and Climate Change Workshop (September 23, 2019); University of Wisconsin-Madison Global Health Institute: Madison, WI, USA, 2020.

2. Cordonier, M.C.; Khalfan, A. Sustainable Development Law: Principles, Practices and Prospects; Oxford University Press: Oxford, UK, 2005; 490p.

3. Atapattu, S. From “Our Common Future” To Sustainable Development Goals: Evolution of Sustainable Development under International Law. Wis. Int. Law J. 2019, 36, 215-246.

4. UN. Sustainable Development Goals Report 2020. Available online: https://unstats.un.org/sdgs/report/2020/ The-Sustainable-Development-Goals-Report-2020.pdf (accessed on 25 September 2020).

5. UN. Transforming Our World: The 2030 Agenda for Sustainable Development. In Proceedings of the A/RES/70/1 United Nations General Assembly, New York, NY, USA, 21 October 2015.

6. World Health Organization. Johannesburg Declaration on Health and Sustainable Development; WHO: Johannesburg, South Africa, 2002; 12p.

7. Dawe, N.K.; Ryan, K.L. The Faulty Three-Legged-Stool Model of Sustainable Development. Conserv. Biol. 2003, 17, 1458-1460. [CrossRef] 
8. Agyeman, J.; Bullard, R.D.; Evans, B.E. Just Sustainabilities: Development in an Unequal World; MIT Press: Boston, MA, USA, 2003; 368p.

9. Atapattu, S.; Simonelli, A.C. Climate Justice, sustainable development and small island states: A case study of the Maldives. In Cambridge Handbook on Environmental Justice and Sustainable Development; Cambridge University Press: Cambridge, UK, 2020; Forthcoming.

10. Friedson-Ridenour, S.; Dutcher, T.V.; Calderon, C.; Brown, L.D.; Olsen, C.W. Gender Analysis for One Health: Theoretical Perspectives and Recommendations for Practice. Ecohealth 2019, 16, 306-316. [CrossRef] [PubMed]

11. Huambachano, M. Enacting food sovereignty in Aotearoa New Zealand and Peru: Revitalizing Indigenous knowledge, food practices and ecological philosophies. Agroecol. Sustain. Food Syst. 2018, 42, 1003-1028. [CrossRef]

12. Sachs, J.D.; Schmidt-Traub, G.; Mazzucato, M.; Messner, D.; Nakicenovic, N.; Rockström, J. Six Transformations to achieve the Sustainable Development Goals. Nat. Sustain. 2019, 2, 805-814. [CrossRef]

13. UN. The Sustainable Development Goals Report; United Nations iLibrary: New York, NY, USA, 2019.

14. Akbulut, B. The 'State' of Degrowth: Economic Growth and the Making of State Hegemony in Turkey; SAGE Publications Ltd.: London, UK, 2019; Volume 2, pp. 513-527.

15. Altieri, M.A.; Toledo, V.M. The agroecological revolution in Latin America: Rescuing nature, ensuring food sovereignty and empowering peasants. J. Peasant Stud. 2011, 38, 587-612. [CrossRef]

16. Gliessman, S.R. Agroecology: Ecological Processes in Sustainable Agriculture; Ann Arbor Press: Ann Arbor, MI, USA, 1998.

17. Myers, S.; Frumkin, H.E. Planetary Health: Protecting Nature to Protect Ourselves; Island Press: Auckland, New Zealand, 2020.

18. The Lancet Planetary Health. Welcome to The Lancet Planetary Health. Lancet Planet. Health 2017, 1, e1. [CrossRef]

19. UN. Universal Declaration of Human Rights; United Nations Human Rights Office of the High Commissioner, UNOHCHR: Geneva, Switzerand, 1948.

20. UN. International Covenant on Civil and Political Rights; United Nations Human Rights Office of the High Commissioner, UNOHCHR: Geneva, Switzerand, 1966.

21. UN. International Covenant on Economic, Social and Cultural Rights (ICESCR); United Nations Human Rights Office of the High Commissioner, UNOHCHR: Geneva, Switzerland, 1966.

22. UN. Convention on the Elimination of all Forms of Discrimination Against Women (CEDAW); United Nations Entity for Gender Equality and the Empowerment of Women: Geneva, Switzerland, 1979.

23. UN United Nations Declaration on the Rights of Indigenous Peoples. Available online: https://www.un.org/ development/desa/indigenouspeoples/declaration-on-the-rights-of-indigenous-peoples.html (accessed on 24 September 2020).

24. Elahi, E.; Weijun, C.; Zhang, H.; Nazeer, M. Agricultural intensification and damages to human health in relation to agrochemicals: Application of artificial intelligence. Land Use Policy 2019, 83, 461-474. [CrossRef]

25. Gilbert, M.; Xiao, X.; Robinson, T.P. Intensifying poultry production systems and the emergence of avian influenza in China: A 'One Health/Ecohealth' epitome. Arch. Public Health 2017, 75, 48. [CrossRef] [PubMed]

26. Rohr, J.R.; Barrett, C.B.; Civitello, D.J.; Craft, M.E.; Delius, B.; DeLeo, G.A.; Hudson, P.J.; Jouanard, N.; Nguyen, K.H.; Ostfeld, R.S.; et al. Emerging human infectious diseases and the links to global food production. Nat. Sustain. 2019, 2, 445-456. [CrossRef] [PubMed]

27. Sellare, J.; Meemken, E.M.; Qaim, M. Fairtrade, Agrochemical Input Use, and Effects on Human Health and the Environment. Ecol. Econ. 2020, 176, 106718. [CrossRef]

28. Sheahan, M.; Barrett, C.B.; Goldvale, C. Human health and pesticide use in Sub-Saharan Africa. Agric. Econ. 2017, 48, 27-41. [CrossRef]

29. Foreman, K.J.; Marquez, N.; Dolgert, A.; Fukutaki, K.; Fullman, N.; McGaughey, M.; Pletcher, M.A.; Smith, A.E.; Tang, K.; Yuan, C.W.; et al. Forecasting life expectancy, years of life lost, and all-cause and cause-specific mortality for 250 causes of death: Reference and alternative scenarios for 2016-40 for 195 countries and territories. Lancet 2018, 392, 2052-2090. [CrossRef]

30. Asociación Red Kuchub'al. Available online: www.kuchubal.org (accessed on 27 August 2020). 
31. Calderón, C.I.; Jerónimo, C.; Praun, A.; Reyna, J.; Santos Castillo, I.D.; León, R.; Hogan, R.; Prado Córdova, J.P. Agroecology-based farming provides grounds for more resilient livelihoods among smallholders in Western Guatemala. Agroecol. Sustain. Food Syst. 2018, 42, 1128-1169. [CrossRef]

32. Deere, C.; Leon, M. Empowering Women: Land And Property Rights in Latin America; University of Pittsburg Press: Pittsburg, PA, USA, 2011; 512p.

33. Deere, C.D. The Feminization of Agriculture: Economic Restructuring in Rural Latin America; UN Research Institute for Social Development: Geneva, Switzerland, 2005; 67p.

34. Chimbuto, J.G.S. Examining a Rights-Based Approach in Women's Land Rights Claims Project in a Culturally Diverse Society: A Comparative Case Study of ActionAid's Intervention in Malawi's Matrilineal and Patrilineal Communities. Master's Thesis, Universitetet i Tromsø, Tromsø, Norway, 2011.

35. Meinzen-Dick, R.; Kovarik, C.; Quisumbing, A.R. Gender and Sustainability. Annu. Rev. Environ. Resour. 2014, 39, 29-55. [CrossRef]

36. Mwangi, M.N.; Oonincx, D.; Stouten, T.; Veenenbos, M.; Melse-Boonstra, A.; Dicke, M.; van Loon, J.J.A. Insects as sources of iron and zinc in human nutrition. Nutr. Res. Rev. 2018, 31, 248-255. [CrossRef]

37. Rumpold, B.A.; Schlüter, O.K. Nutritional composition and safety aspects of edible insects. Mol. Nutr. Food Res. 2013, 57, 802-823. [CrossRef]

38. Stull, V.J.; Finer, E.; Bergmans, R.S.; Febvre, H.P.; Longhurst, C.; Manter, D.K.; Patz, J.A.; Weir, T.L. Impact of Edible Cricket Consumption on Gut Microbiota in Healthy Adults, a Double-blind, Randomized Crossover Trial. Sci. Rep. 2018, 8, 10762. [CrossRef]

39. van Huis, A.; Van Itterbeeck, J.; Klunder, H.; Mertens, E.; Halloran, A.; Muir, G.; Vantomme, P. Edible Insects: Future Prospects for Food and Feed Security; Food and Agriculture Organization of the United Nations: Rome, Italy, 2013.

40. Oonincx, D.G.A.B.; de Boer, I.J.M. Environmental Impact of the Production of Mealworms as a Protein Source for Humans-A Life Cycle Assessment. PLoS ONE 2012, 7, e51145. [CrossRef]

41. Frank, E.; Wimer, G. Implementation of edible insect programmes in developing countries to improve food security: Findings from a training initiative and a train-the-trainer programme. Lancet Glob. Health 2019, 7, S33. [CrossRef]

42. Huambachano, M. Indigenous food sovereignty: Reclaiming food as sacred medicine in Aotearoa New Zealand and Peru. N. Z. J. Ecol. 2019, 43, 3383. [CrossRef]

43. De Schutter, O. Final Report: The Transformative Potential of the Right to Food. Available online: https: //swiftfoundation.org/en/the-transformative-potential-of-the-right-to-food/ (accessed on 4 October 2020).

44. Ropati, H.; (Auckland, New Zealand). Personal Communication, November 2013.

45. Hotene, L.; (Auckland, New Zealand). Personal Communication, December 2014.

46. Quispe, P.; (Auckland, New Zealand). Personal Communication, August 2015.

47. Mihesuah, D.A.; Hoover, E.E. Indigenous Food sovereignty in the United States: Restoring Cultural Knowledge, Protecting Environments, and Regaining Health-New Directions in Native American Studies; University of Oklahoma Press: Norman, OK, USA, 2019; 370p.

48. IDRC Chair in Ecohealth on Urban Air Pollution and Non-Communicable Respiratory Diseases (West Africa). Air Sain Project. Available online: https://www.idrc.ca/fr/project/chaire-en-ecosante-sur-la-pollutionurbaine-de-lair-et-les-maladies-respiratoires-non (accessed on 28 September 2020).

49. Kouao, A.K.R.; N'datchoh, E.T.; Yoboue, V.; Silue, S.; Attoh, H.; Coulibaly, M.; Robins, T. Exposure to indoor and outdoor air pollution among children under five years old in urban area. Glob. J. Environ. Sci. Manag. 2019, 5, 191-202.

50. AKWABA TALANOA, les Jeunes au Coeur de L'action Climatique. In Proceedings of the Local Conference of Youth Côte d'Ivoire (LCOY), Abidjan, Ivory Coast, 22-23 November 2018.

51. Houénou, M.J. Le Droit de L'homme à un Environment Sain: Le cas de la Cote d'Ivoire; DICE: Abidjan, Ivory Coast, 2012.

52. Yoboue, V. Eco Health Chair: Urban Air Pollution and Non-Communicable Respiratory Diseases. In Proceedings of the 4th Air Sain Project Scientific Committee Meeting, Ouidah, Benin, 3 August 2018.

53. UN Air Pollution and Climate Change: Two Sides of the Same Coin. Available online: https://www.unenvironment.org/news-and-stories/story/air-pollution-and-climate-change-twosides-same-coin (accessed on 20 September 2019). 
54. La baisse historique des émissions carbone aura peu d'influence sur le réchauffement climatique. Le Figaro $\mathcal{E}$ AFP, 9 May 2020.

55. Habtezion, S. Gender and Climate Change-Asia and the Pacific; United Nations Development Programme: New York, NY, USA, 2013; 44p.

56. Panwar, N.L.; Kurchania, A.K.; Rathore, N.S. Mitigation of greenhouse gases by adoption of improved biomass cookstoves. Mitig. Adapt. Strateg. Glob. Chang. 2009, 14, 569-578. [CrossRef]

57. Mijatović, D. Human Rights Comment: Living in a Clean Environment: A Neglected Human Rights Concern for All of Us; Council of Europe, Commissioner for Human Rights: Strasbourg, France, 2019.

58. Sarvodaya Shramadana Movement Sri Lanka. Available online: https://www.sarvodaya.org/ (accessed on 23 September 2020).

59. Sarvodaya Women's Movement. Available online: https://www.sarvodaya.org/sarvodaya-womensmovement (accessed on 15 October 2020).

60. Senadeera, B.; (Sarvodaya International Unit, Moratuwa, Sri Lanka). Strategy for Generating Income Leading to Food Security. Powerpoint Presentation. 2020.

61. World Health Organization. WHO Coronavirus Disease (COVID-19) Dashboard. Available online: https: //covid19.who.int/table (accessed on 11 September 2020).

62. Kohona, D.P. Sri Lanka has been successful in countering COVID-19. IDA-InDepthNews, 6 May 2020.

63. WHO Chief lauds Sri Lanka's COVID-19 response. Daily News, 1 April 2020.

64. UN. International Covenant on Economic, Social and Cultural Rights (ICESCR): Article 11; United Nations Human Rights Office of the High Commissioner: Geneva, Switzerland, 1966.

65. UN. International Covenant on Economic, Social and Cultural Rights (ICESCR): Article 12; United Nations Human Rights Office of the High Commissioner: Geneva, Switzerland, 1966.

66. UN. International Covenant on Economic, Social and Cultural Rights (ICESCR): Article 6; United Nations Human Rights Office of the High Commissioner: Geneva, Switzerland, 1966.

67. UN. Declaration on the Right to Development; United Nations Human Rights Office of the High Commissioner: Geneva, Swtizerland, 1986.

68. Uthayakumar, P. The Rights of Indigenous Peoples in Sri Lanka. ESCR E-Newsletter, 16 September 2015; Volume 16.

69. UN. Our Focus: Gender Equity and Equality. United Nations Development Programme Sri Lanka. Available online: https://www.lk.undp.org/content/srilanka/en/home/gender-equality.html (accessed on 15 October 2020).

70. Weeramantry, C. Separate Opinion of Vice-President Weeramantry; ICJ Reports; International Court of Justice: The Hague, The Netherlands, 1996.

71. Thanthriarachchi, A.; Green, S.; Wright, J. Increasing the availability of traditional seeds in Sri Lanka. LEISA Magazine, 2 June 2007; 22-23.

72. Wakkumbure, C.L.K.; Kumarasinghe, K.M.G.P. Sri Lanka, The Haritha Udana Community Seed Bank in Kanthale. In Community Seed Banks: Origins, Evolution and Prospects; Vernooy, R., Shrestha, P., Sthapit, B., Eds.; Routledge: London, UK; New York, NY, USA, 2015; pp. 156-160.

73. World Bank. The World Bank in Sri Lanka. Available online: https://www.worldbank.org/en/country/ srilanka/overview (accessed on 15 October 2019).

74. Einbinder, N.; Morales, H.; Mier Y Terán-Giménez Cacho, M.; Aldasoro, M.; Ferguson, B.G.; Nigh, R. Agroecology on the periphery: A case from the Maya-Achí territory, Guatemala. Agroecol. Sustain. Food Syst. 2019, 43, 744-763. [CrossRef]

Publisher's Note: MDPI stays neutral with regard to jurisdictional claims in published maps and institutional affiliations.

(C) 2020 by the authors. Licensee MDPI, Basel, Switzerland. This article is an open access article distributed under the terms and conditions of the Creative Commons Attribution (CC BY) license (http://creativecommons.org/licenses/by/4.0/). 